\title{
THE EFFECT OF HUMAN RESOURCE COMPETENCY ON FINANCIAL REPORTING
}

\author{
Oleh: \\ Arie Pratama \\ Departemen Akuntansi, Fakultas Ekonomi dan Bisnis, Universitas Padjajaran
}

\begin{abstract}
ABSTRAK
Tujuan penelitian ini adalah untuk mengetahui kelemahan penerapan sistem pengendalian internal di lingkungan Pemerintah Pusat, dan bentuk implementasi sistem pengendalian internal di pemerintah pusat serta kendala dalam menerapkan Sistem Pengendalian Internal Pemerintah di Pemerintah Pusat, dan memberikan rekomendasi solusi dalam mengatasi kendala penerapan tersebut. Metode penelitian yang digunakan adalah kualitatif deskriptif dengan studi kasus di Kementerian Pendayagunaan Aparatur Negara dan Reformasi Birokrasi serta Kementerian Pendidikan dan Kebudayaan, pengumpulan data berdasarkan studi literatur, observasi, dan wawancara. Dilaksanakan sejak bulan Juni 2012 - Oktober 2012. Metode analisis menggunakan metode kualitatif-rasionalistik dan analisis isi. Hasil penelitian ini adalah: (1) Kelemahan penerapan sistem pengendalian internal di lingkungan Pemerintah Pusat masih terbagi atas tiga komponen besar, yang merupakan kelemahan pengendalian akuntansi (accounting control/control activities/ hard control) (2) Bentuk implementasi sistem pengendalian internal di pemerintah pusat masih berfokus pada pengembangan komponen pengendalian aktivitas (accounting control), sementara empat komponen lainnya yang merupakan soft control belum dikembangkan dan (3) Kendala dalam menerapkan Sistem Pengendalian Internal Pemerintah di Pemerintah Pusat terutama adalah dukungan dan bantuan dari instansi terkait yang sangat minim, dan ketiadaan pedoman umum untuk mengevaluasi apakah SPIP sudah berjalan dengan baik atau belum.
\end{abstract}

Kata kunci: Sistem Pengendalian Internal Pemerintahan, Perencanaan dan penganggaran, perbendaharaan, akuntansi, manajemen aset.

\begin{abstract}
The purpose of this study is to determine the internal control system implementation weaknesses, form and obstacles in central government to provide recommendations for solutions in overcoming these implementation. The research method used is descriptive qualitative with case studies in the Ministry of State Apparatus Empowerment and Bureaucratic Reform and the Ministry of Education and Culture, data collection based on literature studies, observations, and interviews. Conducted from June 2012 - October 2012. The analytical method uses qualitative-rationalistic methods and content analysis. The results of this study are: (1) Weaknesses in implementing an internal control system within the Central Government are still divided into three major components, which are weaknesses in accounting controls (accounting control/control activities hard control) (2) The form of implementing an internal control system in the central government still focuses on developing the activity control component (accounting control), while the other four components which are soft control have not been developed and (3) Obstacles in implementing the Government Internal Control System in the Central Government mainly support and assistance from related agencies which is very minimal, and the absence of general guidelines for evaluating whether the SPIP is running well or not
\end{abstract}


JAFTA - Vol 2 Nomor 2, Februari (2021)

Keywords: Government Internal Control System, Planning and budgeting, treasury, accounting, asset management.

\section{PENDAHULUAN}

\section{Latar Belakang}

Krisis moneter Indonesia yang terjadi pada tahun 1998 telah membawa dampak yang luar biasa bagi kehidupan bangsa Indonesia. Krisis moneter yang kemudian meluas menjadi krisis multidimensional, menunjukkan bahwa struktur kehidupan bangsa Indonesia begitu rapuh. kegiatan korupsi, kolusi, dan nepotisme (KKN) yang masih banyak dilakukan di Indonesia menunjukkan bahwa masih banyak hal yang perlu ditata kembali, untuk menciptakan kehidupan Bangsa Indonesia yang tentram, adil dan sejahtera.

$$
\text { Penataan kembali struktur }
$$

kehidupan Bangsa Indonesia dimulai dengan proses reformasi pemerintahan. Pemerintahan Indonesia ditata kembali dengan berbagai reformasi sistem pemerintahan. Bersamaan dengan reformasi pemerintahan pusat-daerah muncul pula tuntutan agar pemerintah, baik pusat ataupun daerah dapat mengelola keuangan secara transparan dan akuntabel. Pengelolaan keuangan di pemerintahan pada masa lalu, tidak pernah dilakukan dengan akuntabel dan transparan, serta tidak memiliki mekanisme yang jelas. Pengelolaan keuangan yang transparan dan akuntabel ini diwujudkan dengan pembentukan rancangan pengelolaan keuangan yang terpadu (unified) dan berlandaskan pada pemantapan kinerja pemerintah (performance).

Reformasi keuangan negara yang ditandai dengan diterbitkannya paket UU Keuangan Negara (UU No. 17 tahun 2003, UU No. 1 tahun 2004, dan UU No. 15 tahun 2004) menjadi dasar hukum untuk dilaksanakannya reformasi total pada pengelolaan keuangan negara. Reformasi dilaksanakan pada siklus pengelolaan keuangan negara sesuai dengan UU Nomor 17 tahun 2003, yang terdiri atas perencanaan, penganggaran, penatausahaan, akuntansi, dan pemeriksaan. Bentuk pertanggungjawaban dari suatu pengelolaan keuangan negara adalah Laporan Keuangan Pemerintahan, yang disusun berdasarkan suatu Standar Akuntansi Pemerintahan. Laporan Keuangan menunjukkan kualitas dari suatu pengelolaan keuangan negara. Laporan keuangan menunjukkan aspek stewardship dan accountability organisasi pemerintah terhadap pengelolaan dana masyarakat (Jones, Rowan and Maurice Pendelbury. 2005).

Fenomena yang terjadi saat ini laporan keuangan pemerintah masih banyak yang tidak berkualitas, buktinya adalah masih rendahnya instansi pemerintah yang 
memperoleh opini WTP. Data di Pemerintah

Pusat menunjukkan bahwa sejak tahun 2004

- 2009, Laporan Keuangan Entitas

Pemerintah Pusat diberikan opini Tidak

Menyatakan Pendapat (TMP), yang merupakan opini tidak baik. Di tingkat pemerintah pusat masih ada Kementerian/Lembaga yang mendapatkan opini tidak wajar atau tidak menyatakan pendapat. Di entitas pemerintahan daerah, kondisinya lebih memprihatinkan, selama tahun 2004 - 2009, entitas pemerintah daerah yang memperoleh opini Wajar Tanpa Pengecualian (WTP), tidak pernah melebihi $5 \%$ dari total keseluruhan entitas pemerintahan (berarti kurang dari 15 enitas pemerintah daerah, dari total 300 lebih entitas pemerintah daerah) yang akan dijelaskan dalam tabel 1 sebagai berikut:

Tabel 1. Deskripsi Opini Laporan Keuangan Entitas Kementerian/Lembaga pada Pemerintah Pusat

\begin{tabular}{cccccccccc}
\multirow{2}{*}{ LKKL } & \multicolumn{10}{c}{ Opini } & Jumlah \\
\cline { 2 - 7 } & WTP & \% & WDP & $\%$ & TW & $\%$ & TMP & $\%$ & \% \\
\hline Tahun 2005* & & & & & & & & & 79 \\
Tahun 2006 & 7 & $9 \%$ & 36 & $46 \%$ & 0 & $0 \%$ & 36 & $46 \%$ & 79 \\
Tahun 2007 & 14 & $18 \%$ & 32 & $40 \%$ & 1 & $1 \%$ & 33 & $41 \%$ & 80 \\
Tahun 2008 & 34 & $41 \%$ & 31 & $37 \%$ & 0 & $0 \%$ & 18 & $22 \%$ & 83 \\
Tahun 2009 & 44 & $56 \%$ & 26 & $33 \%$ & 0 & $0 \%$ & 8 & $10 \%$ & 78 \\
Tahun 2010 & 52 & $63 \%$ & 29 & $35 \%$ & 0 & $0 \%$ & 2 & $2 \%$ & 83 \\
\hline
\end{tabular}

*BPK telah memeriksa LKKL Tahun 2005 tetapi belum memberikan opini

Sumber: Ikhtisar Hasil Pemeriksaan Semester I. 2011. BPK RI

Walaupun reformasi telah berjalan selama kurang lebih 7 tahun, masih saja ditemukan berbagai fenomena yang membuktikan bahwa reformasi pengelolaan keuangan negara belum sepenuhnya berjalan secara efektif. Berbagai kasus yang dapat membuktikan bahwa pengelolaan keuangan negara belum berjalan optimal adalah: (Badan Pemeriksa Keuangan RI. 2010):

1. Belum berjalannya sistem penganggaran berbasis kinerja dan integrasi perencanaan dan penganggaran di pemerintahan belum dilaksanakan secara optimal.

2. Pelaksanaan sistem perbendaharaan (pelaksanaan anggaran di pemerintahan), belum berjalan sesuai dengan prosedur/peraturan perundang-undangan yang berlaku.

3. Sistem akuntansi pemerintahan, sebagai akibat dari pelaksanaan sistem perbendaharaan yang buruk, tidak dapat mencatat transaksi dengan baik, sehingga output yang dihasilkan tidak baik. 
JAFTA - Vol 2 Nomor 2, Februari (2021)

Fenomena kelemahan pengelolaan

keuangan negara dapat dilihat dari tren

kasus kelemahan pengelolaan keuangan

negara dalam tabel 2 berikut:

Tabel 2. Tren Kasus Kelemahan Pengelolaan Keuangan Negara

\begin{tabular}{|c|c|c|c|}
\hline \multirow[t]{2}{*}{ Kelemahan Pengelolaan Keuangan Negara } & \multicolumn{3}{|c|}{ Tahun } \\
\hline & 2008 & 2009 & 2010 \\
\hline \multicolumn{4}{|l|}{ Sistem akuntansi } \\
\hline Pencatatan tidak dilakukan secara akurat & 83 & 96 & 113 \\
\hline Proses penyusunan LK tidak sesuai dengan ketentuan & 93 & 94 & 63 \\
\hline Entitas tidak/terlambat menyampaikan laporan & 5 & 4 & 2 \\
\hline Sistem informasi akuntansi dan pelaporan tidak memadai & 101 & 48 & 47 \\
\hline Lain-lain & - & - & 1 \\
\hline TOTAL & 283 & 242 & 226 \\
\hline \multicolumn{4}{|l|}{ Sistem Perencanaan dan Penganggaran } \\
\hline Perencanaan kegiatan tidak memadai & 33 & 48 & 63 \\
\hline TOTAL & 33 & 48 & 63 \\
\hline \multicolumn{4}{|l|}{ Sistem Pelaksanaan Anggaran } \\
\hline $\begin{array}{l}\text { Mekanisme pemungutan, penyetoran, dan pelaporan serta penggunaan } \\
\text { penerimaan negara dan hibah tidak sesuai dengan ketentuan }\end{array}$ & 22 & 34 & 22 \\
\hline $\begin{array}{l}\text { Penyimpangan pelaksanaan pendapatan dan belanja terhadap ketentuan } \\
\text { peraturan perundang-undangan }\end{array}$ & 12 & 17 & 10 \\
\hline Pelaksanaan belanja di luar mekanisme APBN & 3 & 3 & 6 \\
\hline $\begin{array}{l}\text { Kasus penetapan kebijakan yang salah sehingga menyebabkan hilangnya } \\
\text { pendapatan dan tingginya belanja (inefisiensi) }\end{array}$ & 11 & 29 & 31 \\
\hline Lain-lain & - & - & 2 \\
\hline TOTAL & 48 & 83 & 71 \\
\hline TOTAL SELURUH KASUS & 360 & 373 & 360 \\
\hline
\end{tabular}

Sumber: Ikhtisar Hasil Pemeriksaan (IHPS) Badan Pemeriksa Keuangan RI (2008-2010)

Selain kelemahan pada mekanisme pengelolaan keuangan negara itu sendiri, temuan Badan Pemeriksa Keuangan menyatakan bahwa penyebab kelemahan yang utama adalah kelemahan sistem pengendalian internal organisasi. Kelemahan sistem pengendalian internal umumnya disebabkan oleh (Badan Pemeriksa Keuangan. 2010): 
1. Pencatatan tidak/belum akurat,

2. SDM tidak memadai,

3. Perencanaan yang tidak memadai,

4. Kementerian dan Lembaga tidak menaati ketentuan dan prosedur,

5. Penetapan kebijakan yang tidak tepat,

6. Belum adanya kebijakan akuntansi dan perlakuan akuntansi yang jelas,

7. Belum ditetapkannya prosedur kegiatan,

8. Belum adanya koordinasi dengan pihak terkait, serta

9. Lemahnya pengawasan maupun pengendalian

Penerapan Sistem Pengendalian Internal Pemerintah saat ini sudah berjalan selama 4 tahun $(2008-2012)$, telah terdapat peningkatan dalam kualitas laporan keuangan pemerintah pusat, sehingga diharapkan dengan pelaksanaan reformasi pengelolaan keuangan negara dengan dibantu oleh sistem pengendalian internal pemerintah yang berkualitas, dapat menciptakan kualitas informasi akuntansi yang relevan, dapat diandalkan, dapat dipahami, dan dapat diperbandingkan.Badan Pemeriksa Keuangan dalam IHPS tahun 2008-2011 menyatakan hal yang sama, bahwa meskipun mayoritas entitas kementerian dan lembaga sudah mendapatkan opini WTP dan WDP, namun kasus kelemahan pengelolaan keuangan negara masih saja banyak terjadi.
Frekuensi nya menunjukkan penurunan. Adapun LKKL yang opininya menurun dari WDP menjadi TMP atau WTP menjadi WDP, menunjukkan adanya peningkatan jumlah kasus sistem pengendalian internal. Kelemahan pengelolaan keuangan negara yang terjadi umumnya adalah sama tiap tahun, dan hal ini menunjukkan bahwa pada entitas kementerian dan lembaga, belum ada suatu upaya maksimal untuk meningkatkan sistem pengendalian internal

Berbagai penelitian di luar negeri menunjukkan kecenderungan bahwa diperlukan adanya dukungan regulasi, SDM, serta komitmen pimpinan dalam pelaksanaan sistem pengendalian internal ini. Penelitian Reginato et. al (2005) menunjukkan bahwa Pemerintah Italia sukses menerapkan reformasi pengelolaan keuangan, dimana salah satu faktor penentu kesuksesan adalah sistem pengendalian internal pemerintah yang berkualitas.

\section{Rumusan Masalah}

Berdasarkan latar belakang penelitian di atas, peneliti merumuskan masalah penelitian sebagai berikut:

1. Apa saja kelemahan penerapan sistem pengendalian internal di lingkungan Pemerintah Pusat?

2. Bagaimana bentuk implementasi sistem pengendalian internal di pemerintah pusat? 
3. Apa saja kendala dalam menerapkan sistem pengendalian internal pemerintah di pemerintah pusat?

\section{Tujuan Penelitian}

Maksud penelitian ini adalah untuk mengetahui bagaimana penerapan sistem pengendalian internal di lingkungan pemerintahan, terutama pada lingkungan pemerintah pusat yang terdiri atas kementerian dan lembaga. Tujuan penelitian ini dirumuskan sebagai berikut:

1. Mengetahui kelemahan penerapan sistem pengendalian internal di lingkungan Pemerintah Pusat.

2. Mengetahui bentuk implementasi sistem pengendalian internal di pemerintah pusat?

3. Mengetahui kendala dalam menerapkan Sistem Pengendalian Internal Pemerintah di Pemerintah Pusat, dan memberikan rekomendasi solusi dalam mengatasi kendala penerapan tersebut.

\section{RERANGKA TEORITIS}

\section{Sistem Pengendalian Internal}

\section{Pemerintahan}

\section{Sistem Pengendalian Internal}

Pengendalian internal didefinsikan oleh COSO (2013) sebagai:

“a process, effected by an entity's board of directors, management and other personnel, designed to provide reasonable assurance regarding the achievement of objectives in the following categories:

1. Effectiveness and efficiency of operations.

2. Reliability of financial reporting.

3. Compliance with applicable laws and regulations. "

Sistem pengendalian internal bekerja pada berbagai level dari efektifitas. Pengendalian internal dapat menilai apakah ketiga kategori di atas telah efektif, jika direktur/pimpinan dan manajemen memiliki keyakinan memmadai bahwa:

1. Mereka memahami bagaimana tujuan operasi entitas akan dicapai.

2. Laporan Keuangan yang dipublikasikan telah disusun secara andal.

3. Telah patuh terhadap peraturan dan hokum yang berlaku

4. Pengendalian internal adalah suatu prosese, efektifitasnya diukur dari kondisi atau keadaan pada satu proses ke proses lainnya.

Pengendalian internal terdiri dari 5 komponen yang saling berkaitan. Komponen ini diturunkan dari bagaimana manajemen menjalankan bisnis, dan terintegrasi pada proses manajemen. Walaupun komponen tersebut ada di semua entitas, entitas kecil dan menengah akan melaksanakan pengendalian internal 
berbeda dengan entitas besar. Pengendalian dalam entitas kecil dan menengah lebih tidak formal dan kurang terstruktur, namun dengan kondisi seperti itu, entitas kecil masih memiliki pengendalian internal yang efektif. Komponen-komponennya adalah sebagaimana dapat digambarkan pada Gambar 1 dibawah ini:

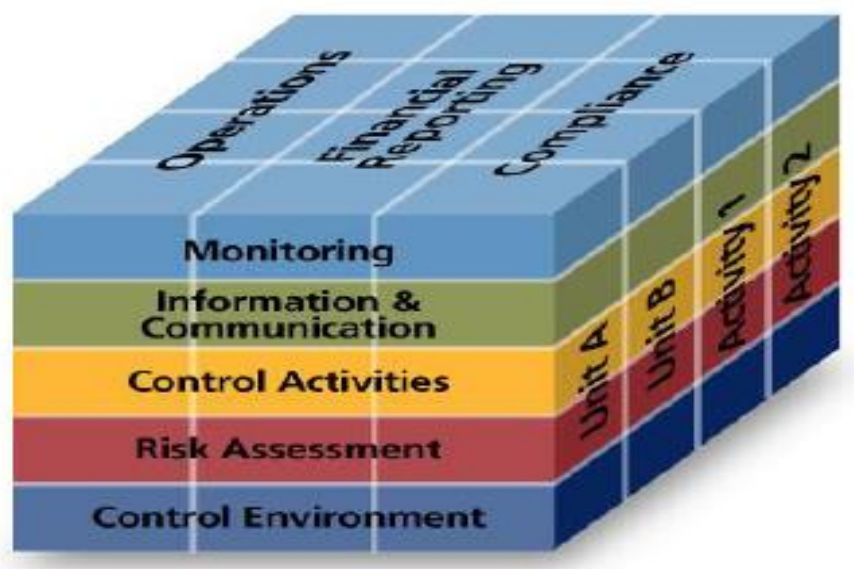

Gambar 1. Kerangka Pengendalian Internal

\section{Lingkungan Pengendaliann}

Lingkungan

pengendalian

menentukan jalannya organisasi, dan dapat mempengaruhi kesadaran akan pengendalian pada anggota organisasi tersebut. Ini adalah dasar dari komponen lain dalam pengedalian internal, dimana komponen ini menyediakan suatu disiplin dan struktur dasar. Faktor-faktor dalam lingkungan pengendalian termasuk integritas, nilai etika, dan kompetensi dari aparatur, folosofi manajemen dan gaya operasi, penugasan dan pelimpahan tugas dan wewenang, arahan dan perhatian yang diberikan oleh manajemen.

\section{Penilaian Resiko}

Setiap entitas menghadapi berbagai macam resiko dari sumber eksternal maupun internal yang harus dinilai. Langkah awal untuk melakukan penilaian resiko yaitu pembentukan tujuan, dan dihubungkan pada berbagai level kegiatan operasi entitas dan penilaian resiko dilaksanakan dengan konsisten pada entitas. Penilaian resiko adalah identifikasi dan analisis resiko yang terkait dengan pencapaian tujuan, sehingga menyediakan dasar untuk menentukan bagaimana pengelolaan resiko. Karena kondisi ekonomi, industri, hukum, dan operasi akan selalu berubah, maka diperlukan mekanisme untuk mengidentifikasi dan menanggulangi resiko-resiko terkait atas kondisi-kondisi tersebut. 


\section{Monitoring}

Sistem pengendalian internal harus dimonitor sebagai proses yang menilai kualitas dari kinerja sistem . Hal ini dapat dicapai dengan memonitor aktivitas, melakukan evaluasi secara terpisah atau kombinasi dua kegiatan tersebut. Monitoring dilaksanakan secara terus menerus dalam setiap bentuk operasi. Mencakup juga kegiatan monitoring rutin yang dilakukan oleh manajemen dan aktivitas pengawasan, serta tindakan lain yang diambil terkait dengan monitoring. Ruang lingkup dan frekuensi evaluasi serta pengawasan akan bergantung pada penilaian resiko dan efektifitas monitoring on-going. Kelemahan atas pengendalian internal harus dilaporkan kepada atasan, dan kelemahan yang fatal/serius langsung dilaporkan kepada direksi atau komisaris.

\section{Sistem Pengendalian Internal Pemerintah (SPIP) sesuai PP 60 Tahun 2008}

Dalam Peraturan Pemerintah No 60 tahun 2008, sistem pengendalian intern didefinisikan sebagai:

"proses yang integral pada

tindakan dan kegiatan yang

dilakukan secara terus menerus oleh pimpinan dan seluruh pegawai untuk memberikan keyakinan memadai atas tercapainya tujuan organisasi melalui kegiatan yang efektif dan efisien, keandalan pelaporan keuangan, pengamanan aset negara, dan ketaatan terhadap peraturan perundang-undangan yang berlaku."

PP No. 60/2008 menetapkan bahwa sistem pengendalian intern diselenggarakan secara menyeluruh di lingkungan pemerintah pusat dan pemerintah daerah. Pemerintah pusat terdiri atas Kementerian dan Lembaga. Dalam PP tersebut, Kementerian adalah organisasi dalam pemerintahan Republik Indonesia yang dipimpin oleh menteri untuk melaksanakan tugas dalam bidang tertentu dan Lembaga adalah lembaga pemerintah nonkementerian yang dibentuk untuk melaksanakan tugas tertentu berdasarkan peraturan perundang-undangan, termasuk sekretariat jenderal pada lembaga negara/komisi independen dan lembaga pemerintah setingkat kementerian negara. Pemerintah Daerah terdiri atas gubernur, bupati, walikota, dan perangkat daerah sebagai unsur penyelenggara pemerintahan daerah.

Tujuan ditetapkannya SPIP oleh pemerintah adalah untuk mencapai pengelolaan keuangan negara yang efektif, efisien, transparan, dan akuntabel dan untuk memberikan keyakinan yang memadai bagi tercapainya efektivitas dan efisiensi 
pencapaian tujuan penyelenggaraan pemerintahan negara, keandalan pelaporan keuangan, pengamanan aset negara, dan ketaatan terhadap peraturan perundangundangan.

SPIP menurut PP No. 60/2008, terdiri atas lima unsur pengendalian intern, yaitu Lingkungan Pengendalian, Penilaian Risiko, Aktivitas Pengendalian, Informasi dan komunikasi serta pemantauan. Namun demikian penerapan SPIP yang mengacu pada Internal Control versi COSO bukanlah suatu pekerjaan yang mudah. Dari pengamatan tampak bahwa masih banyak tantangan yang harus dihadapi baik dalam membangun 'hard control', maupun 'soft control' yang memadai. Saat ini, pengembangan 'hard control' SPIP banyak yang masih sebatas formalitas belaka. Salah satu contoh adalah penerapan manajemen kinerja di sektor publik. Pengembangan manajemen kinerja yang dirintis melalui Inpres Nomor 7 Tahun 1999 masih menemui banyak kendala. Walaupun saat ini sudah banyak instansi pemerintah yang mampu menyusun Laporan Kinerja dan Akuntabilitas Pemerintahan (LAKIP), namun belum dimanfaatkan sebagai alat dalam pengukuran kinerja dan perbaikan kebijakan publik.

\section{Sistem Pengendalian Internal dalam Pengelolaan Keuangan Pemerintah}

Dalam melaksanakan pengelolaan keuangan, pemerintah sebagai entitas perlu memastikan bahwa pengelolaan keuangan berjalan secara efisien dan ekektif serta patuh pada ketentuan yang berlaku. Penyimpangan-penyimpangan pada pengelolaan keuangan negara dapat mengakibatkan kerugian negara dan merusak tata kelola pemerintahan yang baik.

Tuntutan akan akuntabilitas terhadap pengelolaan keuangan negara, memerlukan adanya suatu sistem pengendalian intern yang mendorong seluruh instansi penerima dana anggaran tersebut untuk memberdayakan kapasitas yang dimiliki (Ardan. 2009). Hal ini dilakukan agar Menteri, Pimpinan/Kepala Instansi dan Gubernur/Bupati/Walikota sebagai penerima dana anggaran dapat memberikan jaminan bahwa anggaran (APBN/APBD) yang sudah diserahkan kepada seluruh penerima anggaran telah digunakan sebaikbaiknya secara efektif dan efisien.

Sistem pengendalian internal bekerja dalam pengelolaan keuangan pemerintah untuk memastikan bahwa pengelolaan keuangan dilakukan secara efisien dan efektif, sehingga seluruh rangkaian proses pengelolaan keuangan mulai dari perencanaan hingga pertanggungjawaban betul-betul dapat menghasilkan output dan outcome yang diharapkan dan dapat 
JAFTA - Vol 2 Nomor 2, Februari (2021)

menciptakan akuntabilitas keuangan pemerintahan (Indriasih dan Koeswayo, 2014).

Sistem perencanaan dan penganggaran pada suatu entitas akan menyesuaikan dengan ukuran dan struktur organisasi, jenis produk atau layanan yang diberikan, sistem akuntansi, preferensi pengelola/manajemen entitas, dan lainlainnya. Perencanaan dan pengendalian merupakan fase awal dalam pengelolaan keuangan pemerintah, sehingga kesalahan fase perencanaan dan penganggaran dapat berdampak luas, terutama kegagalan pelaksanaan kegiatan/program pelayanan publik, serta ukuran kinerja program pelayanan publik yang tidak sesuai dengan rencana. Secara umum, sistem perencanaan dan penganggaran harus memiliki pengendalian internal yang baik, untuk mencegah dari resiko-resiko tersebut di atas. Berbagai bentuk pengendalian internal di siklus perencanaan dan penganggaran, termasuk (PER 500/K/2010. BPKP):

1. Entitas pemerintahan memiliki suatu fungsi dan struktur organisasi dalam tim anggaran/tim perencanaan yang jelas, terdapat suatu penjelasan tertulis mengenai alur kerja dalam proses perencanaan dan penganggaran, dan terdapat suatu dokumen kebijakan dan prosedur perencanaan dan penganggaran.
2. Terdapat kesesuaian antara rencana jangka panjang dan rencana strategis pemerintah terhadap rencana jangka pendek pemerintah.

3. Terdapat suatu teknik-teknik yang efektif dan dapat mendukung penyusunan anggaran, misalnya analisis sensitivitas anggaran, teknik peramalan (forecasting), penggunaan asumsi-asumsi, dsb.

4. Terdapat prosedur untuk membandingkan kinerja aktual dengan yang direncanakan dan hasil aktual dengan hasil yang dianggarkan atau mengidentifikasi dan menganalisis varians, mempelajari dampaknya pada usaha yang tersisa, dan memulai tindakan perbaikan yang diperlukan.

5. Fleksibilitas atau rencana kontinjensi untuk bereaksi terhadap perubahan signifikan dalam asumsi-asumsi anggaran.

Pada siklus perbendaharaan, pelaksanaan anggaran mencakup sistem penerimaan kas dan pengeluaran kas di entitas pemerintahan. Pada sistem penerimaan kas, resiko lebih rendah dibandingkan dengan sistem pengeluaran kas. Bentuk pengendalian internal pada siklus perbendaharaan adalah (PER 500/K/2010. BPKP): 
1. Terdapat pengawasan secara internal terkait dengan aspek perbendaharaan, baik penerimaan kas maupun pengeluaran kas

2. Terdapat pengamanan fisik atas saldo kas

3. Bendahara memahami secara teknis tentang aspek perbendaharaan dalam pengelolaan keuangan negara, dan

4. Terdapat kebijakan dan prosedur untuk penerimaan dan pengeluaran kas di pemerintahan.

Pada siklus manajemen aset, resiko yang paling besar adalah pada tahap pembelian aset (procurement). Pengadaan aset memiliki resiko semisalnya fraud atau kelebihan belanja yang menyebabkan inefisiensi pada pemerintah. Berikut adalah pengendalian internal untuk pengadaan aset (PER 500/K/2010. BPKP):

1. Terdapat Kebijakan dan prosedur untuk pembelian barang, termasuk mekanisme pengadaan barang yang sesuai dengan hukum yang berlaku.

2. Terdapat suatu Struktur organisasi dan administrasi yang memastikan pengadaan yang efektif dan efisien , seperti: pengadaan dengan sistem eprocurement, bahan atau kualitas yang diperlukan sesuai dan harga ekonomis, dari sumber/vendor/supplier yang telah dikenal.

3. Terdapat Proses seleksi untuk memastikan vendor/supplier yang paling ekonomis dan baik dalam segi kualitas, sehingga pembelian ini cukup murah dan memiliki syarat vendor yang dapat dijadikan rekanan.

4. Terdapat standar harga atau analisis standar biaya yang dilakukan dalam setiap tindakan pembelian.

Pada akuntansi, sistem pengendalian internal adalah berupa accounting control, yaitu suatu pengendalian untuk memastikan bahwa proses pencatatan dalam siklus akuntansi telah dilakukan secara benar dan sesuai. Bentuk pengendalian internal pada siklus akuntansi, adalah (PER 500/K/2010. BPKP):

1. Terdapat pengecekan internal (internal check) antara bukti transaksi dengan dokumen akuntansi yang dilakukan oleh pihak independen

2. Aparatur akuntansi memahami sistem dan standar dalam melaksanakan akuntansi pemerintahan

3. Terdapat sistem akuntansi yang dapat diandalkan dalam menyusun suatu laporan keuangan.

\section{Kerangka Pemikiran}

Pemerintahan dengan New Public Management Theory mulai mengalihkan 
fokus pengelolaan dengan mengambil praktek-praktek terbaik bisnis, salah satunya adalah GCG, yang diadopsi menjadi GGG, dengan acuan seperti yang dikemukakan oleh UNDP (ada 9 kriteria). Implementasi GGG, melalui berbagai referensi terbukti dapat meningkatkan kinerja organisasional.

Salah satu kinerja organisasional yang utama adalah pengelolaan keuangan (managerial finance)

Isu-isu yang mengemuka dalam reformasi pengelolaan keuangan negara adalah akuntabilitas publik, value for money, akuntansi dan auditing sektor publik serta pemerintahan. (Mardiasmo.2016:17) Tema sentral reformasi keuangan negara adalah mewujudkan masyarakat madani, terciptanya good governance, dan menciptakan model pembangunan yang berkeadilan (Mardiasmo.2016), yang intinya adalah penciptaan tata kelola penyelenggara pemerintahan yang baik (good governance).

Untuk menciptakan pengelolaan keuangan negara yang berkualitas, maka dilakukan reformasi dan perubahan pada siklus pengelolaan keuangan negara. Siklus pengelolaan keuangan negara terdiri dari 4 hal, yaitu:
a. Perencanaan dan penganggaran,
b. Pelaksanaan anggaran/ perbendaharaan, termasuk manajemen aset
c. Akuntansi,

d. Pertanggungjawaban, dan Pemeriksaan.

Tujuan dilaksanakannya reformasi pengelolaan keuangan negara adalah untuk tercapainya pengelolaan pemerintahan yang baik (Good Government Governance). Secara spesifik, reformasi pengelolaan keuangan negara dilakukan pada siklus pengelolaan keuangan negara, yaitu:

1. Pada siklus perencanaan dan penganggaran, diterapkannya penganggaran berbasis kinerja serta integrasi perencanaan dan penganggaran untuk memastikan bahwa kegiatan yang direncanakan merupakan kegiatan yang memang diperlukan, serta anggaran untuk melaksanakan kegiatan tersebut dapat dijelaskan pada masyarakat.

2. Pada siklus perbendaharaan, diterapkannya berbagai standar dan prosedur operasional untuk penerimaan dan pengeluaran negara serta manajemen aset negara untuk memastikan bahwa kegiatan berjalan sesuai dengan rencana kerja dan anggaran.

3. Pada siklus manajemen aset, diterapkannya sistem pengelolaan aset terpadu yang meliputi analisis kebutuhan, penilaian ekonomis, perencanaan, penganggaran, penentuan harga, pengadaan, 
penggunaan dan pemeliharaan, serta pengalihan dan penghapusan, dimaksudkan agar informasi aset lebih baik dan dapat diandalkan, sekaligus mengefisienkan dan mengefektifkan pemanfaatan aset di Pemerintahan.

4. Pada siklus akuntansi, diterapkannya standar akuntansi pemerintahan dan penerapan double entry accounting untuk memastikan bahwa semua kegiatan dan transaksi pada tahap perbendaharaan dicatat dan dilaporkan dalam suatu laporan keuangan.

Dalam pelaksanaan di lapangan, pengelolaan keuangan akan sangat dipengaruhi oleh berbagai implementasi kebijakan keuangan dan non keuangan (Kewo, 2017). Berbagai resiko pemerintahan dapat terjadi, sehingga dapat mengganggu jalannya reformasi. Pengendalian dilakukan pada umumnya untuk mencegah terjadinya penyimpangan atau kerugian negara, atau kesalahan pengurusan administrasi keuangan negara.

Salah satu alat kendali keuangan negara adalah PP 60 tahun 2008 tentang SPIP. SPIP sudah dijalankan di level instansi atau kementerian. Selain sistem pengendalian internal, pemahaman entitas (process owner) terhadap resiko terjadinya penyimpangan atau kerugian negara adalah sangat penting. Berbagai referensi menyebutkan bahwa resiko dapat menyebabkan pada terjadinya penyimpangan di instansi pemerintah, yang dapat berujung pada rusaknya reputasi pemerintahan, dan tidak terpercayanya kinerja pemerintahan.

Kualitas informasi akuntansi dapat lebih terpercaya jika pengendalian internal ada pada organisasi. Sistem pengendalian internal akan menjamin bahwa kualitas pelaporan keuangan menjadi lebih baik (reliability of financial reporting), sesuai dengan tujuan pengendalian internal itu sendiri (Nurlis dan Yadiati, 2017).

Sistem pengendalian internal bekerja pada level entitas (entity level control) dan pada aktivitas (activity level control). Lingkungan pengendalian merupakan pengendalian awal, sekaligus merupakan suatu filosofi yang menunjukkan concern suatu entitas dalam pengendalian intern. Lingkungan pengendalian merupakan dasar untuk semua komponen pengendalian intern, menyediakan disiplin dan struktur. Lingkungan pengendalian dapat juga dilihat dari tindakan dan kebijakan yang mencerminkan sikap manajemen puncak dan pemilik suatu entitas mengenai pengendalian dan arti pentingnya.

Penaksiran risiko dimaksudkan untuk menetapkan derajat signifikansi risiko agar dapat ditentukan langkah-langkah reaktif selanjutnya. Risiko yang signifikan harus dikelola (managed), misalnya dihilangkan, dikurangi, atau dibagi/sebar 
(shared) ke beberapa bagian sehingga tingkat risiko menjadi tingkat risiko yang dapat ditolerir oleh organisasi. Namun, seringkali risiko tidak dapat dihilangkan dan butuh biaya yang besar untuk menguranginya, manajemen organisasi harus mempertimbangkan apakah manfaat dari pengurangan risiko tersebut melebihi biaya yang harus dikeluarkan untuk mengurangi risiko. Resiko dapat dibagi menjadi resiko yang ada pada level entitas, dan resiko pada level kegiatan/aktivitas

Aktivitas pengendalian menyajikan kebijakan dan prosedur dalam setiap aktivitas yang ditetapkan manajemen untuk menjamin bahwa semua arahan manajemen dilaksanakan dalam rangka mencapai tujuan organisasi. Aktivitas pengendalian dapat beragam, tergantung pada sifat aktivitas.

Informasi dan komunikasi merupakan pengidentifikasian, penangkapan, dan pertukaran informasi dalam suatu bentuk dan waktu yang memungkinkan orang melaksanakan tanggung jawab mereka. Sedangkan makna komunikasi dan informasi dalam aspek pengelolaan keuangan merupakan metode yang dipakai untuk mengidentifikasi, menggabungkan, mengklasifikasikan, mencatat, dan melaporkan peristiwaperistiwa untuk menjamin akuntabilitas untuk aktivitas pengelolaan keuangan yang terkait

Monitoring merupakan penilaian efektivitas rancangan operasi struktur pengendalian intern secara periodik dan terus-menerus oleh manajemen untuk melihat apakah pengelolaan telah dilaksanakan dengan semestinya dan telah diperbaiki sesuai dengan keadaan. Dengan kata lain, pemantauan merupakan proses yang menentukan kualitas kinerja pengendalian intern sepanjang waktu. Informasi untuk penilaian dan perbaikan dapat berasal dari berbagai sumber meliputi studi atas struktur pengendalian intern yang ada, laporan aparat pengawas internal pemerintah (APIP), laporan penyimpangan atas aktivitas pengendalian, dsb.

Sistem pengendalian internal pemerintah merupakan bagian integral dari pengelolaan keuangan pemerintahan, sehingga pengelolaan keuangan pemerintahan dapat menjadi lebih baik, terbantu oleh sistem pengendalian internal yang baik pula (Afiah dan Azwari, 2015) Kerangka pemikiran di atas, dapat dijelaskan dalam bentuk gambar sbb: 


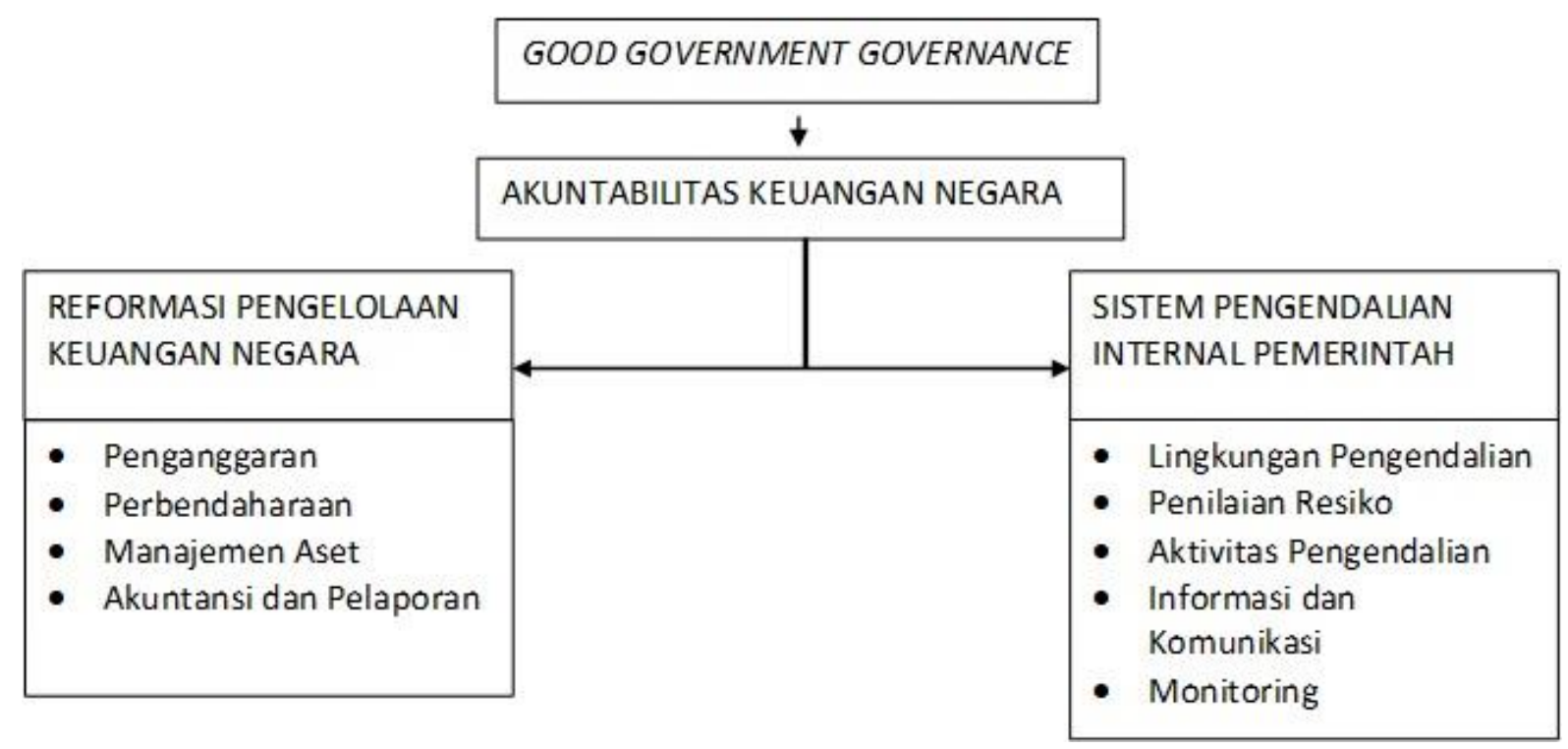

Gambar 2. Bagan Kerangka Pemikiran

\section{METODE PENELITIAN}

Objek penelitian ini adalah Penerapan Sistem Pengendalian Internal Pemerintah (SPIP). Populasi dalam penelitian ini adalah seluruh Kementerian dan Lembaga yang ada di lingkungan Pemerintah Pusat Republik Indonesia. Kementerian dan Lembaga yang ada di lingkungan Pemerintah Pusat Republik Indonesia berjumlah 83 (delapan puluh tiga), sesuai dengan kondisi terakhir pada tahun 2012 (BPK. 2011)

Pemilihan sampel yang dilakukan oleh penulis menggunakan teknik judgmental sampling Penelitian ini merupakan penelitian kualitatif yang memiliki tujuan menggambarkan fenomena penetapan pengendalian internal di pemerintahan, maka penulis memilih sampel berdasarkan level kelemahankekuatan sistem pengendalian internal pemerintahan. Berdasarkan kriteria judgment tersebut maka penulis memilih sampel sebagai berikut:

1. Sampel Kementerian/Lembaga yang memiliki keunggulan pada pengendalian internal adalah Kementerian Pendayagunaan Aparatur Negara dan Reformasi Birokrasi

2. Sampel Kementerian/Lembaga yang memiliki kelemahan pada pengendalian internal adalah Kementerian Pendidikan dan Kebudayaan

Dalam perspektif kualitatif, penelitian ini termasuk deskriptif kualitatif, karena bertujuan meneliti masalah-masalah yang membutuhkan studi mendalam. (Burhan Bungin. 2007). Penelitian deskriptif kualitatif termasuk pada penelitian eksplorasi dan memainkan 
JAFTA - Vol 2 Nomor 2, Februari (2021)

peranan yang amat penting dalam menciptakan hipotesis atau pemahaman orang tentang berbagai variabel sosial. Penelitian ini mendeskripsikan pengendalian internal pemerintah, terutama mendeteksi kelemahan-kelemahan, dengan harapan dapat menciptakan rekomendasi atau saran perbaikan atas kelemahan pengendalian internal tersebut.

Klasifikasi kategori terbagi dalam lima komponen utama sistem pengendalian internal pemerintahan, yaitu:

1. Lingkungan Internal

2. Penilaian Resiko

3. Pengendalian Aktivitas

4. Informasi dan Komunikasi

5. Monitoring

Pembahasan dan analisis data akan dilakukan pada lingkup pengelolaan keuangan negara, sesuai dengan siklus pengelolaan keuangan negara, yaitu:

1. Perencanaan dan penganggaran

2. Perbendaharaan

3. Manajemen Aset

4. Akuntansi

Pengumpulan data dilakukan dengan menggunakan teknik secara kualitatif, yang meliputi beberapa teknik berikut ini:

a) Metode observasi,

Observasi akan dilakukan dengan melakukan walkthrough (menelusuri dan mengamati) proses pengelolaan keuangan pada Kementerian/Lembaga yang dijadikan sampel penelitian. Observasi akan meliputi pengamatan langsung terhadap proses:

- Perencanaan dan penganggaran

- Perbendaharaan

- Manajemen Aset

- $\quad$ Akuntansi

b) Metode Wawancara,

Wawancara akan dilakukan dengan metode wawancara kepada informan di Kementerian/Lembaga. Informan dari kementerian/lembaga berasal dari pihak pelaksana keuangan (bagian Keuangan terkait) dan pihak pengawas (Inspektorat Jenderal dari masing-masing

Kementerian/Lembaga). Wawancara akan dilakukan dengan menggunakan pertanyaan terbuka (open question), dengan maksud untuk membebaskan responden untuk mendeskripsikan jawaban sedetail mungkin, tanpa dibatasi oleh suatu pilihan jawaban.

c) Metode Dokumenter, Dokumentasi yang akan digunakan dalam penelitian ini adalah:

- $\quad$ Buku teks

- Artikel ilmiah (jurnal, tesis, disertasi)

- Dokumen SOP SPIP yang diterapkan di Kementerian/Lembaga 
- Dokumen terkait Sistem Pengendalian

Internal

\section{Pemerintah}

d) Metode Penelusuran Data On-Line, Dalam melakukan penelitian ini, peneliti juga menggunakan berbagai dokumen yang dapat diunduh melalui situs internet.

Analisis kualitatif yang digunakan dalam penelitian akan terbagi berdasarkan sumber data, yaitu sbb:

a. Untuk data wawancara, akan digunakan Metode Analisis Isi (Content Analysis). Analisis isi adalah teknik penelitian untuk membuat inferensi-inferensi yang dapat ditiru (replicable), dan sahih data dengan memperhatikan konteksnya (Burhan Bungin. 2007). Analisis isi akan dilakukan dengan pendekatan secara pragmatis, didasari oleh teori akuntansi yang ada.

b. Untuk data studi literatur dan dokumentasi akan digunakan metode analisis kualitatif-rasionalistik. Metode kualitatif-rasionalistik ini didasarkan atas pendekatan holistik berupa suatu konsep umum (grand concepts) yang diteliti pada objek tertentu (spesific object), yang kemudian mendudukkan kembali hasil penelitian yang didapat pada konsep umumnya.
Uji validitas dan reliabilitas data dari wawancara akan dilakukan, secara kualitas dengan melihat kredibilitas informan yang ditunjuk, meliputi jabatan, pengetahuan, dan pengalaman informan. Informan yang akan diwawancara merupakan informan yang mengetahui dan menguasai sistem pengendalian internal dan aspek pengelolaan keuangan terkait, sehingga diharapkan bias dan error pada data penelitian tidak terjadi. Peneliti juga memasukkan pihak pelaksana dan pihak pengawas sebagai mekanisme untuk crosscheck, apabila ada data/pernyataan/jawaban yang berbeda.

\section{HASIL PENELITIAN DAN PEMBAHASAN}

\section{Hasil Uji Kualitas Data}

Dalam wawancara ini, peneliti mewawancara responden yang mewakili 2 unsur dalam akuntansi pemerintahan, yaitu pelaksana keuangan (participant) dan pengawas keuangan/inspektorat (oversee). Alasan untuk melakukan wawancara kepada 2 pihak ini adalah karena informan mengetahui penerapan SPIP dari sudut pandang sebagai pelaksana proses bisnis (participant) dan pengawas proses bisnis (oversee). Wawancara dengan masingmasing responden berlangsung selama $2 \mathrm{jam}$ dengan seluruh transkrip wawancara telah direkam/disalin. 
Masing-masing responden di tiap kementerian diwakili oleh dua orang, sehingga total responden adalah empat orang. Responden dipilih berdasarkan keluasan wawasan dan pengetahuan mengenai kondisi obyektif yang ada di Kementerian/Lembaga, sehingga hasil wawancara valid dan reliable. Responden yang diwawancara dalam penelitian yang dilakukan adalah:

1. Kementerian Pendidikan dan Kebudayaan

- Dari pihak pelaksana (participant), adalah Bapak Yusrial Bachtiar

- Dari pihak pengawas (oversee), adalah Bapak Haryono Umar

2. Kementerian Pendayagunaan Aparatur Negara dan Reformasi Birokrasi

- Dari pihak pelaksana (participant), adalah Bapak Edi Sudaryanto

- Dari pihak pengawas (oversee), adalah Ibu Hatni.

\section{Hasil Penerapan SPIP pada Kementerian}

\section{PAN dan RB}

Peneliti mengumpulkan data penelitian dengan melakukan observasi pada proses pengelolaan keuangan negara yang dilakukan di Kementerian PAN dan $\mathrm{RB}$, terutama untuk melihat implementasi sistem pengendalian internal pemerintahan yang dilaksanakan pada tahapan pengelolaan keuangan negara. Peneliti menjadi observan non-partisipan, dimana peneliti hanya melihat proses pengelolaan keuangan dan sistem pengendalian internal tanpa terlibat menjadi pelaku dari proses itu sendiri.

Berdasarkan hasil observasi yang dilakukan pada level umum Kementerian PAN dan RB, peneliti menemukan bahwa sistem pengendalian internal pemerintah telah diterapkan sesuai dengan PP Nomor 60 tahun 2008 tentang Sistem Pengendalian Internal Pemerintahan. Kementerian PAN dan RB. Untuk melaksanakan sistem pengendalian internal pemerintahan, Kementerian PAN dan RB telah membuat dokumentasi terkait dengan Sistem Pengendalian Internal Pemerintahan, berupa Pedoman Implementasi Sistem Pengendalian Internal Pemerintahan yang mengacu pada PP 60 tahun 2008.

Peneliti melihat secara umum dalam proses pengelolaan keuangan, bahwa sistem pengendalian internal pemerintahan yang dijalankan hanya sebatas accounting control (hard control), yaitu pengendalian yang bertujuan untuk menjaga reliabilitas informasi laporan keuangan. Komponen pengendalian internal yang dijalankan baru sebatas control activities, sementara komponen lain belum dijalankan. Beberapa komponen pengendalian aktivitas yang 
penulis amati selama observasi pada siklus pengelolaan keuangan di Kementerian PAN dan RB adalah:

1. Siklus Perencanaan dan Penganggaran a. Pada perencanaan kegiatan, peneliti melihat bahwa masih ada kebingungan aparatur bagian penganggaran dalam menentukan kode mata anggaran keluaran dan jenis kegiatan, Kebingungan ini disebabkan adanya intepretasi yang berlainan dalam memahami peraturan teknis terkait penganggaran.

b. Pada penganggaran, peneliti melihat bahwa dengan adanya konsep anggaran berbasis kinerja, maka penyusunan RKA (Rencana Kerja Anggaran) telah melihat/merujuk pada Rencana Strategis dan Rencana Jangka Panjang di Kementerian PAN dan RB. Kementerian PAN dan RB telah memiliki program kerja yang jelas pada bidang Reformasi Birokrasi, sehingga memudahkan aparatur bagian penganggaran untuk menyusun program kerja.

\section{Siklus Perbendaharaan}

a. Pada sistem penerimaan kas dan pengeluaran kas, peneliti melihat bahwa Kementerian
PAN dan RB sudah memiliki standar prosedur operasi (SOP) untuk penerimaan kas dan pengeluaran kas yang merujuk pada Peraturan Menteri Keuangan yang disusun oleh Kementerian Keuangan.

b. Peneliti mengamati bahwa Penerimaan kas dan pengeluaran kas sudah diverifikasi sesuai dengan prosedur, namun masih ditemukan kasus keterlambatan verifikasi dan pertanggungjawaban, disebabkan karena dokumen yang salah atau pengajuan SPJ tanpa disertai bukti belanja.

3. Siklus Manajemen Aset

a. Peneliti mengamati bahwa Kementerian PAN dan RB telah melaksanakan pengadaan barang dan jasa secara elektronik, sesuai dengan ketentuan Peraturan Presiden Nomor 54 tahun 2011 tentang Pedoman Pengadaan Barang dan Jasa.

b. Peneliti mengamati bahwa Kementerian PAN dan RB juga telah

mengintegrasikan/menginput data inventarisasi dan penilaian aset ke dalam SIMAK-BMN. 
4. Siklus Akuntansi dan Pelaporan Keuangan

a. Kementerian PAN dan RB telah melaksanakan akuntansi keuangan di pemerintahan melalui dua sistem akuntansi, yaitu Sistem Akuntansi Instansi (SAI) dan Sistem Akuntansi Keuangan Negara (SAKUN) pada level Satuan Kerja. SAI dan SAKUN juga telah terintegrasi menggunakan software akuntansi yang diberikan oleh Kementerian Keuangan,sehingga proses penyusunan laporan keuangan berlangsung dengan baik.

\section{Penerapan SPIP pada Kementerian}

\section{Pendidikan dan Kebudayaan}

Peneliti mengumpulkan data penelitian dengan melakukan observasi pada proses pengelolaan keuangan negara yang dilakukan di Kementerian Pendidikan dan Kebudayaan, terutama untuk melihat implementasi sistem pengendalian internal pemerintahan yang dilaksanakan pada tahapan pengelolaan keuangan negara. Peneliti menjadi observan non-partisipan, dimana peneliti hanya melihat proses pengelolaan keuangan dan sistem pengendalian internal tanpa terlibat menjadi pelaku dari proses itu sendiri.
Berdasarkan hasil observasi yang dilakukan pada level umum Kementerian PAN dan RB, peneliti menemukan bahwa sistem pengendalian internal pemerintah telah diterapkan sesuai dengan PP Nomor 60 tahun 2008 tentang Sistem Pengendalian Internal Pemerintahan. Kementerian PAN dan RB. Untuk melaksanakan sistem pengendalian internal pemerintahan, Kementerian PAN dan RB telah membuat dokumentasi terkait dengan Sistem Pengendalian Internal Pemerintahan, berupa Pedoman Implementasi Sistem Pengendalian Internal Pemerintahan yang mengacu pada PP 60 tahun 2008.

Peneliti melihat secara umum dalam proses pengelolaan keuangan, bahwa sistem pengendalian internal pemerintahan yang dijalankan hanya sebatas accounting control (hard control), yaitu pengendalian yang bertujuan untuk menjaga reliabilitas informasi laporan keuangan. Komponen pengendalian internal yang dijalankan baru sebatas control activities, sementara komponen lain belum dijalankan. Beberapa komponen pengendalian aktivitas yang penulis amati selama observasi pada siklus pengelolaan keuangan di Kementerian PAN dan RB adalah:

1. Siklus Perencanaan dan Penganggaran a. Pada perencanaan kegiatan, peneliti melihat bahwa masih ada kebingungan aparatur bagian penganggaran dalam 
JAFTA - Vol 2 Nomor 2, Februari (2021)

menentukan kode mata anggaran keluaran dan jenis kegiatan, Kebingungan ini disebabkan adanya intepretasi yang berlainan dalam memahami peraturan teknis terkait penganggaran.

b. Pada penganggaran kegiatan, peneliti melihat bahwa Kementerian Pendidikan dan Kebudayaan memiliki unit kerja (satuan kerja) yang banyak sehingga menyulitkan dalam mengintegrasikan seluruh kegiatan dalam level kementerian. Belum adanya suatu mekanisme penyatuan/integrasi yang baik di level Kementerian Pendidikan dan Kebudayaan.

c. Pada penganggaran, peneliti melihat bahwa kesulitan utama penganggaran adalah masih belum terpolanya penyusunan Rencana Kerja dan Anggaran, dan lambatnya pertanggungjawaban anggaran, yang menyebabkan anggaran tahun 2012 Kementerian Pendidikan dan Kebudayaan sempat ditunda pelaksanaannya oleh Kementerian Keuangan.

d. Pada perencanaan dan penganggaran, terutama pada instansi yang menerapkan Pengelolaan Keuangan Badan Layanan Umum (PK-BLU), masih ada beberapa instansi yang masih belum menyusun Rencana Bisnis dan Anggaran yang layak, sehingga tidak memenuhi ketentuan hukum tentang PK-BLU

2. Siklus Perbendaharaan

a. Pada sistem penerimaan kas dan pengeluaran kas, peneliti melihat bahwa Kementerian Pendidikan dan Kebudayaan sudah memiliki standar prosedur operasi (SOP) untuk penerimaan kas dan pengeluaran kas yang merujuk pada Peraturan Menteri Keuangan yang disusun oleh Kementerian Keuangan.

b. Peneliti mengamati bahwa Penerimaan kas dan pengeluaran kas sudah diverifikasi sesuai dengan prosedur, namun masih ditemukan kasus keterlambatan verifikasi dan pertanggungjawaban, disebabkan karena dokumen yang salah atau pengajuan SPJ tanpa disertai bukti belanja.

3. Siklus Manajemen Aset

a. Peneliti mengamati bahwa Kementerian Pendidikan dan 


\begin{abstract}
Kebudayaan telah
melaksanakan pengadaan

barang dan jasa secara

elektronik, sesuai dengan

ketentuan Peraturan Presiden

Nomor 54 tahun 2011 tentang

Pedoman Pengadaan Barang

dan Jasa, namun belum semua

instansi melaksanakan

pengadaan barang secara

elektronik, dan belum seluruh

Pejabat Pembuat Komitmen

memiliki sertifikasi pengadaan barang dan jasa dari LKPP.

b. Peneliti mengamati bahwa Kementerian Pendidikan dan Kebudayaan juga telah mengintegrasikan/menginput data inventarisasi dan penilaian aset ke dalam SIMAK-BMN, namun belum semua satuan kerja melakukan integrasi dengan SIMAK-BMN.
\end{abstract}

4. Siklus Akuntansi dan Pelaporan Keuangan

a. Kementerian Pendidikan dan Kebudayaan telah melaksanakan akuntansi keuangan di pemerintahan melalui dua sistem akuntansi, yaitu Sistem Akuntansi Instansi (SAI) dan Sistem Akuntansi Keuangan Negara (SAKUN) pada level Satuan Kerja. SAI dan SAKUN juga telah terintegrasi menggunakan software akuntansi yang diberikan oleh Kementerian Keuangan

\section{Pembahasan Hasil Penelitian}

Berdasarkan hasil penelitian, maka dapat dideskripsikan bahwa secara umum implementasi Sistem Pengendalian Internal Pemerintahan sesuai dengan amanat PP No. 60 tahun 2008 ditanggapi hampir sama oleh kedua kementerian (Kementerian PAN dan RB serta Kementerian Pendidikan dan Kebudayaan) yang menjadi sampel dalam penelitian ini. Kedua kementerian awalnya sama-sama memiliki harapan yang positif terhadap konsep sistem pengendalian internal, bahwa sistem pengendalian internal pemerintah dapat meningkatkan kualitas pengelolaan keuangan negara dengan mengeliminasi bentuk-bentuk kelemahan pengelolaan keuangan negara yang selama ini ditemukan.

Pada tahapan teknis pelaksanaan sistem pengendalian internal pemerintah, ditemukan kesulitan bahwa pedoman untuk implementasi tidak memadai atau membingungkan pelaksana. Apabila melihat hasil wawancara dengan pihak Kementerian PAN dan RB, dukungan instansi terkait, terutama Badan Pengawasan Keuangan dan Pembangunan (BPKP) selaku pembina SPIP masih terbatas ada 
penyusunan pedoman umum dan juga sosialisasi, namun belum sampai pada level yang lebih teknis.

Pola pemeriksaan SPIP yang dilakukan oleh auditor eksternal ataupun internal ternyata tidak mengikuti komponen SPIP yang terdiri dari 5 komponen, namun diarahkan pada 3 komponen yang seluruhnya merupakan komponen utama dari pengendalian aktivitas, saat ini belum ada suatu pola pemeriksaan untuk komponen diluar pengendalian aktivitas. Sehingga, belum ada suatu pola pemeriksaan untuk menunjukkan apakah SPIP sudah mencapai tujuannya atau belum. Melihat deskripsi yang disampaikan, pemeriksaan SPIP cenderung masing melihat pada poin pertama tujuan SPIP, yaitu keterandalan informasi keuangan, sementara efisiensi dan efektivitas operasi, serta kepatuhan terhadap hukum dan undang-undang yang berlaku belum dijalankan.

Berdasarkan studi yang dilakukan oleh Institute of Internal Auditors (1999), berbagai entitas kesulitan mengevaluasi komponen lain di luar komponen aktivitas pengendalian, yaitu:

1. Sulit untuk membuat manajemen suatu entitas memahami apa yang dimaksud dengan soft control dan bagaimana dampaknya terhadap proses di organisasi.
2. Manajemen level menengah dan aparatur teknis sangat sulit diyakinkan mengenai manfaat dan pemahaman atas soft control.

3. Manajemen kesulitan mengidentifikasi metodologi audit yang terbaik untuk soft control.

4. Sulit untuk mengubah ekspektasi pemikiran dari entitas/ pimpinan entitas terhadap pemeriksaan pengendalian internal, banyak yang masih berekspektasi bahwa pengendalian internal adalah tidak terkait dengan soft control.

5. Mengavaluasi soft control mensyaratkan kepercayaan yang tinggi antara auditee dengan auditor.

6. Sulit untuk memperoleh bukti audit terkait dengan soft control.

\section{HASIL PENELITIAN DAN PEMBAHASAN}

Berdasarkan hasil penelitian di atas, maka peneliti mengambil simpulan sbb:

1. Kelemahan penerapan sistem pengendalian internal di lingkungan Pemerintah Pusat masih terbagi atas tiga komponen besar, yang sebenarnya merupakan kelemahan pengendalian internal dari sudut pandang pengendalian akuntansi (control activities/ hard control) yaitu: ○ Kelemahan sistem pengendalian akuntansi dan pelaporan, yaitu 
kelemahan sistem pengendalian yang terkait kegiatan penc atatan akuntansi dan pelaporan keuangan.

○ Kelemahan sistem pengendalian pelaksanaan anggaran pendapatan dan belanja, yaitu kelemahan pengendalian yang terkait dengan pemungutan dan penyetoran penerimaan negara /daerah /perusahaan milik negara /daerah serta pelaksanaan program dan kegiatan pada entitas yang diperiksa.

○ Kelemahan struktur pengendalian intern, yaitu kelemahan yang terkait dengan ada atau tidak adanya struktur pengendalian intern atau efektivitas struktur pengendalian intern yang ada dalam entitas yang diperiksa.

2. Bentuk implementasi sistem pengendalian internal di pemerintah pusat masih berfokus pada pengembangan komponen pengendalian aktivitas (accounting control), sementara empat komponen lainnya yang merupakan soft control belum dikembangkan. Sehingga tujuan pengendalian internal yang terpenuhi baru keterandalan informasi keuangan, sementara efisiensi dan efektivitas operasi serta kepatuhan terhadap hukum dan peraturan perundang-undangan belum dapat dicapai.

3. Kendala dalam menerapkan Sistem Pengendalian Internal Pemerintah di Pemerintah Pusat terutama adalah dukungan dan bantuan dari instansi terkait yang sangat minim, dan ketiadaan pedoman umum untuk mengevaluasi apakah SPIP sudah berjalan dengan baik atau belum.

Berdasarakan simpulan penelitian di atas, peneliti memberikan saran sebagai berikut:

1. Hasil penelitian menunjukkan bahwa kelemahan pengendalian internal masih berfokus pada pengendalian akuntansi dan tidak menyinggung bentuk pengendalian lainnya. Peneliti memberikan saran kepada BPKP, selaku Pembina SPIP, BPK selaku auditor eksternal pemerintah dan juga instansi pemerintahan terkait untuk menyusun kerangka kerja implementasi SPIP berbasis lima komponen, sehingga tujuan SPIP secara keseluruhan dapat tercapai.

2. Hasil penelitian menunjukkan bahwa kendala dalam implementasi SPIP adalah lemahnya bantuan/dukungan dari instansi terkait. Peneliti mengusulkan kepada BPKP, selaku pembina SPIP dan Kementerian/ 
Lembaga untuk membuat suatu program kerja dengan kerangka waktu yang jelas untuk mengimplementasikan SPIP pada Kementerian/Lembaga, sehingga seluruh kementerian/lembaga mengimplementasikan SPIP dengan langkah yang seragam, dan hasil implementasi dapat dibandingkan antar entitas Kementerian/Lembaga.

3. Hasil penelitian menunjukkan bahwa kendala penerapan SPIP adalah ketiadaan pedoman evaluasi SPIP. BPKP dan Kementerian terkait perlu segera menyusun pedoman evaluasi SPIP yang seragam, sehingga entitas kementerian/lembaga memiliki dasar objektif untuk mengukur efektifitas SPIP. Badan Pemeriksa Keuangan juga dapat menggunakan pedoman evaluasi SPIP ini sebagai dasar pemeriksaan SPIP ketika melakukan pemeriksaan laporan keuangan pemerintah.

4. Penelitian ini mengambil objek pemerintah pusat, karena pada level pemerintah pusat SPIP relatif sudah dijalankan di level Kementerian/Lembaga, untuk peneliti selanjutnya, dapat mempertimbangkan untuk mengambil entitas pemerintahan daerah, dengan catatan penelitian selanjutnuya dapat dilakukan, apabila seluruh pemerintah daerah sudah menerapkan SPIP.

\section{DAFTAR PUSTAKA}

Afiah, Nur Nunuy, and Peny Cahaya Azwari. 2015. The Effect of the Implementation of Government InternalControl System (GICS) on the Quality of Financial Reporting of the Local Government and its Impact on thePrinciples of Good Governance: A Research in District, City, and Provincial Government in South Sumatera.Procedia-Social and Behavioral Sciences211: 81118

Ardan Adi Perdana. 2009. Peranan Auditor Internal Pemerintah dalam Memperkuat Sistem Pengendalian Internal Pemerintah. Makalah disampaikan pada Konvensi Nasional Akuntansi VI Ikatan Akuntan Indonesia Bandung.

Badan Pemeriksa Keuangan. Ikhtisar Hasil Pemeriksaan Tahun 2008, 2009, dan 2010

Badan Pengawasan Keuangan dan Pembangunan. 2010. Peraturan Kepala Badan Pengawasan Keuangan Dan Pembangunan Nomor: Per-500/K/2010 Tentang Pedoman Pemetaan (Diagnostic Assessment) Terhadap Penerapan Sistem Pengendalian Intern 
JAFTA - Vol 2 Nomor 2, Februari (2021)

Pemerintah Di Lingkungan Instansi Pemerintah

Burhan Bungin. 2007. Penelitian Kualitatif:

Komunikasi, Ekonomi, Kebijakan

Publik dan Ilmu Sosial Lainnya. Jakarta: Prenada Media Group

Indriasih, D., \& Koeswayo, P. S. (2014). The effect of government apparatus competence and the effectiveness of government internal control toward the quality of financial reporting in local goverment. Research Journal of Finance and Accounting, 5(20), $38-47$.

Institute of Internal Auditors. 1999. Soft Control: A Dallas /Fort Worth Government Perspective. Dallas: IIA.

Jones, Rowan and Maurice Pendlebury. 2000. Public Sector Accounting 5th edition. London: Financial Times Prentice Hall.

Kewo, C. L. (2017). The influence of internal control implementation and managerial performance on financial accountability local government in Indonesia. International Journal of Economics and Financial Issues, 7(1), 293-297.

Mardiasmo, 2016. Akuntansi Sektor Publik. Penerbit Andi.

Nurlis, \& Yadiati, W. (2017). The Influence of Internal Control Effectiveness , Information Technology Utilization and Human Resources Competence on Local Government Financial Reporting Quality ( Survey on SKPD Banten Provincial Government and Serang City ), 8(12), 111-124.

Republik Indonesia. 2003. Undang-Undang Nomor 17 Tahun 2003 Tentang Keuangan Negara.

Republik Indonesia. 2004. Undang-Undang Nomor 1 Tahun 2004 Tentang Perbendahraan Negara.

Republik Indonesia. 2008. Peraturan Pemerintah No 60 Tahun 2008 tentang Sistem Pengendalian Internal Pemerintahan 